\title{
Greedy Parabolics: Wind flow direction within the deflation basin of parabolic dunes is governed by deflation basin width and depth
}

Thomas A.G. Smyth ${ }^{* 182}$, Irene Delgado-Fernandez ${ }^{3}$, Derek W.T. Jackson ${ }^{4}$, Brian Yurk ${ }^{5}$, Paul Rooney ${ }^{6}$

*Corresponding author: t.ag.smyth@hud.ac.uk

${ }^{1}$ Department of Biological and Geographical Sciences, School of Applied Sciences, University of Huddersfield, Huddersfield, UK

${ }^{2}$ Beach and Dune Systems (BEADS) Laboratory, School of the Environment, Flinders University, Adelaide, Australia, 5041

${ }^{3}$ Geography Department, Edge Hill University, Ormskirk, Lancashire, UK

${ }^{4}$ School of Geography \& Environmental Science, Ulster University, Coleraine, BT52 1SA, Northern Ireland, UK.

${ }^{5}$ Hope College, Mathematics Department, PO Box 9000, Holland, MI, USA.

${ }^{6}$ Liverpool Hope University, Department of Geography and Environmental Science, Faculty of Science, Hope Park, Liverpool, UK.

\section{Abstract}

Parabolic dunes are ' $U$ ' or ' $V$ '-shaped aeolian landforms that form on pre-existing sand deposits. Their morphology consists of an upwind deflation basin, bordered by often vegetated trailing arms and a downwind depositional lobe. The orientation of parabolic dunes is commonly attributed to the prevailing or resultant wind direction. Consequently, the orientation of parabolic dunes stabilised by vegetation growth has been used as a proxy for wind direction during past climates in several studies. However, the ability or extent of parabolic dune morphology to steer incident wind flow parallel to the orientation of the landform, and thus migrate in the direction of the current landform orientation rather than prevailing wind direction, is unknown.

By numerically modelling wind flow within the deflation basin of eight parabolic dunes, we demonstrate for the first-time, that wind flow direction within the deflation basin of a parabolic dune is highly controlled by the depth and width of the deflation basin. The greater the depth-width ratio of the landform (i.e. the deeper and narrower the deflation basin), the greater the degree of flow steering relative to the axis orientation of the landform. These results demonstrate that future studies must exercise caution when using parabolic dune orientation as a direct proxy for prevailing wind direction, especially where parabolic dunes have a relatively high deflation basin depth-width ratio, as the deflation basin of these landforms may continue to migrate in an antecedent wind direction.

Keywords: Parabolic dune; paleowind; computational fluid dynamics; near surface wind flow 


\section{Introduction}

Parabolic dunes are ' $U$ ' or ' $V$ '-shaped aeolian landforms that form on pre-existing sand deposits. Their morphology consists of an upwind deflation basin, bordered by often vegetated trailing arms and a downwind depositional lobe (Goudie, 2011; Yan and Baas, 2015). Parabolic dune morphology can range from simple 'hairpin' shapes to more complex crenulated 'digitate' morphologies (Pye and Tsoar, 2008). Multiple parabolic dunes often form in close proximity to one another (e.g. White Sands, New Mexico) resulting in compound morphologies where dunes merge and override one another (Wolfe and David, 1997). Parabolic dunes occur in a range of environments including coastal dunes (Arens et al., 2004; Delgado-Fernandez et al., 2018; Hansen et al., 2009; Robertson-Rintoul, 1990), temperate grasslands (Wolfe and David, 1997) and semi-arid environments (Ardon et al., 2009) throughout the Americas, Europe, Australasia, North Africa, South Africa, the Middle East and North East Asia (Figure 2 in Yan and Baas, 2015).

The orientation of parabolic dunes commonly aligns with and is attributed to prevailing (Bailey and Bristow, 2004; Finnigan et al., 1990; Wolfe and Hugenholtz, 2009; Duran et al., 2008) or the resultant wind direction (Landsberg, 1956; Jennings, 1957; Pye, 1982; Ritchie, 1992). As a result, the orientation of parabolic dunes stabilised by vegetation growth has been used as a proxy for wind direction during past climates in several studies (Kilibarda et al., 2014; Kiss et al., 2009; Girardi and Davis, 2010). Discrepancies do however exist in active dunes between prevailing and resultant wind direction and dune orientation. Studying the migration of dunes in Aberffraw, Wales, Bailey and Bristow (2004), purport that spatial differences in water table give rise to the deviation of dune orientation from the prevailing wind direction, as wetter conditions limit sediment mobility. Landsberg (1956) showed that local topography such as a small hill (Newborough Warren, Wales) or cliff (Forvie, Scotland) may substantially modify local winds, causing a discrepancy between the prevailing regional wind direction and dune orientation (Lynch et al., 2010; Jackson et al., 2011; 2013; 2015). The theories proposed by Bailey and Bristow (2004) and Landsberg (1956) however, both lack quantitative evidence. Alternatively, Hansen et al. (2009) suggested that prevailing incident winds, oblique to the orientation of the dune, become steered and aligned with the central axis of the dune and therefore, once established the orientation of a parabolic dune will be resistant to change. Hansen et al. (2009) demonstrated this steering effect in the deflation basin of a large parabolic dune using anemometers located $1.2 \mathrm{~m}$ above the surface. In their study, even when wind flow measured on the beach was approximately $60^{\circ}$ oblique to the orientation of the landform, near surface wind flow inside the deflation basin was steered along the axis of the dune. 
Finnigan et al. (1990) similarly queried "can a dune, established during times of one wind direction and then partially stabilized by vegetation, steer wind from a new direction so that new dune growth is along the axis of the existing dune rather than in the new prevailing wind direction". To test this, Finnigan et al. (1990) simulated approach wind directions from $0^{\circ}$ to $180^{\circ}$ in relation to the dune axis, over a 1000:1 scaled cardboard model of a coastal parabolic dune, painted with a thin layer of oil inside a wind tunnel. Near surface wind flow, recorded by streaks in the oil film, indicated that the direction of wind flow within the deflation basin for approach winds $0^{\circ}, 7.5^{\circ}$ and $15^{\circ}$ relative to landform orientation were largely unchanged. A zone of wind flow separation, defined as regions of recirculating wind flow by Finnigan et al. 1990, occurred in lee of the landform, but were axis aligned and took the form of counterrotating vortices. For approach winds $30^{\circ}$ oblique to the dune axis, the zone of separation in lee of the landform was no longer axis-aligned, but its orientation associated with the incident wind flow direction. At an incident wind direction of $30^{\circ}$, wind flow in the dune deflation basin was no longer steered by the topography, a result drastically different to Hansen et al. (2009). Finnigan et al. (1990) also noted that in zones of flow separation flow patterns appeared to change from 'paired' vortices (our term, following the descriptions of Savory and Toy, 1986; Sutton and McKenna, 2008; and Gillies et al., 2014) to vortex rollers (Bauer et al., 2013) when the incident wind direction was greater than $30^{\circ}$ to the orientation of the dune. The flow visualisation technique of applying a thin layer of oil to a topographic surface, used in Finnigan et al. (1990), does however exaggerate the extent of flow separation (Maltby, 1962). Although partially vegetated dunes present different roughness conditions Furthermore, near surface flow measurements over a topography covered in a thin layer of oil are unlikely to be representative of the flow dynamics over the much rougher surface of a partially vegetated sand dune. Actual sand dunes offer heterogeneous roughness conditions that are simply not replicated by the topographic model form proposed by Finnegan et al. (1990). Iteratively increasing surface roughness on aeolian landforms has been found to increase flow separation on lee slopes and retard the presence of near surface jet on stoss slopes (Hesp and Smyth, 2016).

Yan and Bass (2015), Anthonsen et al. (1995), Kiss et al. (2009) and Pye and Tsoar (2008) suggest that incident winds oblique to the prevailing conditions produce asymmetric hairpin parabolic dune morphologies. However, at present only results from Finnigan et al. (1990) provide scientists with an indication of the approach angle at which oblique winds are insufficiently steered by the existing topography to create asymmetric morphologies. The discrepancy between the results of Hansen et al. (2009) and Finnigan et al. (1990) signals that the approach angle at which flow is no longer steered along the deflation basin, may be specific to dune morphology. Quantifying the ability of parabolic dunes to steer incident wind flows along their axis orientation is important not only for 
the identification of prevailing and paleowind directions, but also to better understand how the orientation of parabolic dunes is likely to change in the future. Due to anthropogenic climate change, by 2100 prevailing wind directions in the north east United States of America and south east Australia, two regions in which parabolic dunes are relatively common, are expected to change by 5 to $15^{\circ}$ clockwise and over $15^{\circ}$ anticlockwise respectively (McInnnes et al., 2011).

The overall purpose of this study was to examine the interaction between parabolic dune topography and near surface wind flow within the deflation basin, specifically investigating the extent to which topography reorients wind flow within the landforms deflation basin. This question stems from the discrepancy between deflation basin flow direction measured by Hansen et al. (2009) and Finnigan et al. (1990). The disparity between their results indicates that the point at which wind flow is no longer steered along the axis orientation of the landforms deflation basin may be specific to dune morphology. This investigation simulated landform - wind flow interactions using a validated computational fluid dynamics model at nine parabolic dunes located in the United Kingdom to assess the effect of incident-wind direction on airflow reorientation with the deflation basin of the parabolic dune.

\section{Study Sites}

The interaction between parabolic dune topography and modelled near surface wind flow was initially investigated using nine incident wind directions at three coastal parabolic dunes in Ravenmoels Sandhills, Morfa Dyffryn and Newborough Warren (Figure 1). These three sites were selected as they represented a broad range deflation basin widths and depths (Table 1 and Figure 9). To statistically test the hypothesis that the degree of wind flow reorientation within the deflation basin of a parabolic dune is related to landform morphology, incident wind from two directions at an additional six coastal parabolic dunes was modelled (Figure 1). Numerically-modelled wind flow was also compared with measured field data at parabolic dune in Ravenmoels Sandhills, England. 


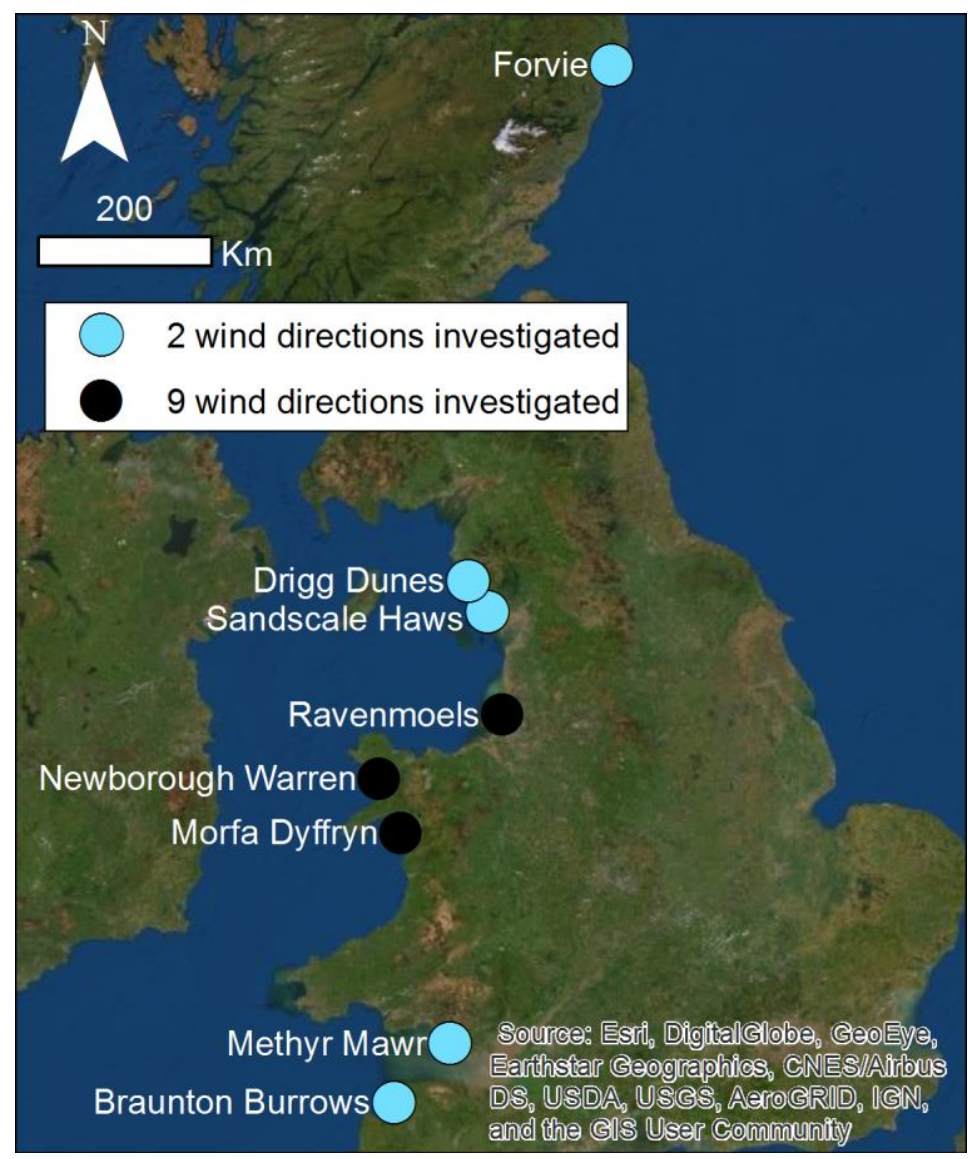

Figure 1. Satellite image of the British Isles denoting the location the eight parabolic dunes investigated. At sites denoted with a black dot, incident wind flow was simulated from nine directions, $-60^{\circ}$ to $+60^{\circ}$ in increments of $15^{\circ}$, relative to the axis orientation of the landform. At sites denoted with a blue dot incident wind flow was simulated from two directions, $-45^{\circ}$ and $+45^{\circ}$, relative to the axis orientation of the landform.

The topographies of all sites were determined from airborne LiDAR surveys flown between 2011 and 2015 (Table 1). Deflation basin width was defined as the width between the crests of trailing arms at the upwind 'opening' of the landform, following Ritchie (1992). Deflation basin depth was defined as the average height of the crest of the trailing arms, minus the average height of the flat surface of the deflation basin. The crest of each trailing arm was identified and mapped where a clear distinction was present between the windward and leeward slope of the trailing arm, this process was aided by calculating the aspect of each topographic LiDAR surface (Burrough and McDonell, 1998). The trailing arms were deemed to terminate where the crest of the trailing arm started to become perpendicular to the orientation of the deflation basin at the depositional lobe of the dune, a location termed the "crest turning point" by Robertson-Rintoul (1990). The deflation basin was defined as the area between the crest of each trailing arm, including the inward marginal/erosional walls (Pye, 1982). Three key metrics were used to characterise the morphology of each landform, 
deflation basin width, deflation basin depth and the depth to width ratio of each landforms deflation basin (Table 1). 

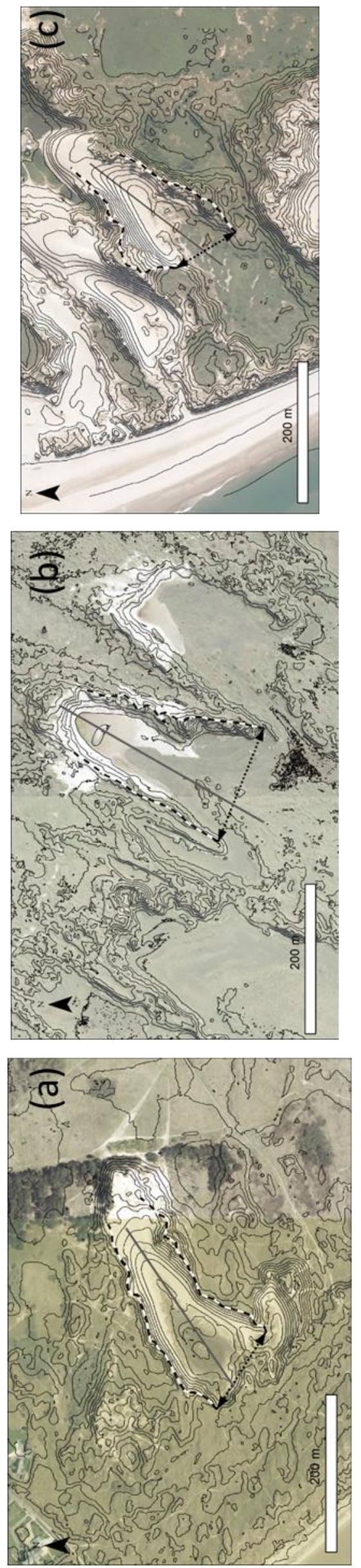
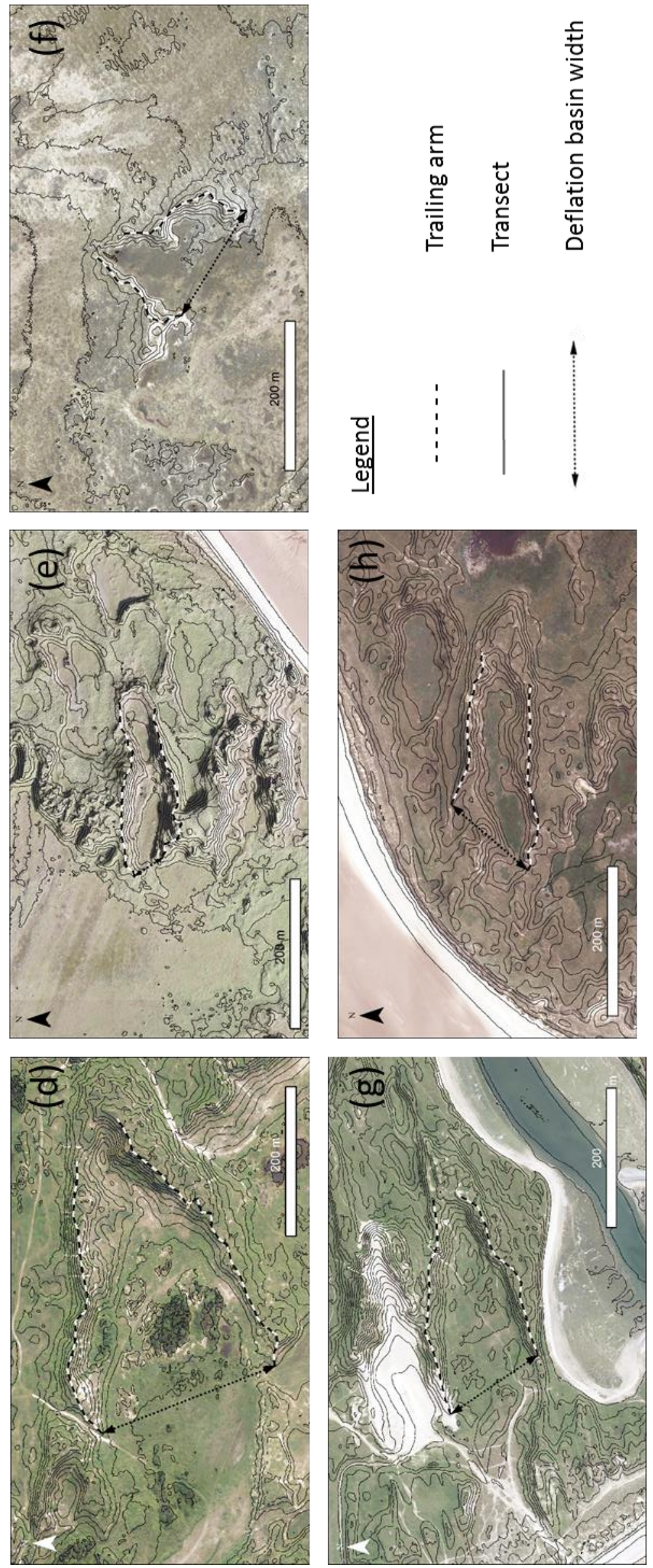
Figure 2. Aerial imagery and $\mathbf{2} \mathrm{m}$ contours of the Parabolic dunes investigated at (a) Ravenmoels Sandhills, (b) Newborough Warren, (c) Morfa Dyffryn, (d) Braunton Burrows, (e) Drigg Dunes (f) Forvie, (g) Merthyr Mawr Warren and (h) Sandscale Haws. The grey line through the axis of images $a, b$ and $c$ indicates the location of the transects in Figure 8.

\subsection{Ravenmoels Sandhills, England.}

The Ravenmoels Sandhills are situated on the Sefton Coast in north west England. The sand dunes on the Sefton Coast extend $16 \mathrm{~km}$ alongshore and up to $4 \mathrm{~km}$ inland, constituting the largest coastal dune field in England (Esteves et al., 2012). The parabolic dune investigated at Ravenmoels Sandhills, known locally as 'Devil's Hole' originates from a coastal blowout that has elongated over the last 70 years at an average rate of $4.5 \mathrm{~m} \mathrm{yr}^{-1}$ (Read, 1995) in a north westerly direction $\left(64^{\circ}\right.$ ) (Figure 2a). The deflation basin of the current landform is $250 \mathrm{~m}$ long, tapering from its widest point of $117 \mathrm{~m}$ in the south west to a minimum of $70 \mathrm{~m}$ in the north east toward the depositional lobe (Figure 2a). The erosional walls of the deflation basin range average $11 \mathrm{~m}$ in height and are mostly unvegetated. Devil's Hole has a deflation basin depth to width ratio of 0.09 .

\subsection{Newborough Warren, Wales.}

Newborough Warren is a Natural Nature Reserve located in south eastern Ynys Môn (Anglesey), north Wales (Figure 1). The dunes at Newborough Warren extend $5 \mathrm{~km}$ alongshore and $2.5 \mathrm{~km}$ inland. The parabolic studied at Newborough Warren is located $800 \mathrm{~m}$ inland from the foredune and extends $290 \mathrm{~m}$ in length. The landforms width tapers from a maximum of $164 \mathrm{~m}$ at the southern 'entrance' of the deflation basin to $85 \mathrm{~m}$ at the depositional lobe (Figure $2 \mathrm{~b}$ ). The deflation basin is on average $7 \mathrm{~m}$ deeper than the trailing arms that border it. The landform was subject to a dune rejuvenation process in March 2013, whereby vegetation from the surface of the north east of the deflation basin was scraped down to bare sand, as well as the windward slopes of the depositional lobe (Figure $2 \mathrm{~b}$ ). Preceding this intervention only very small patches and pathways of bare sand existed on the deflation basin and depositional lobe. The landform has a deflation basin depth to width ratio of 0.04 .

\subsection{Morfa Dyffryn}

Morfa Dyffryn is a National Nature Reserve located in Gwynedd on the north east coast of Cardigan Bay, in north Wales. The beach and dunes at Morfa Dyffryn form part of a cuspate foreland that extends $3 \mathrm{~km}$ inland at its widest point. At present, the site contains $2.6 \mathrm{~km}^{2}$ of coastal dunes. The remaining land has been converted from sand dunes to agricultural land and an airfield (formerly Royal Aircraft Establishment Llanbedr). The parabolic dune studied at Morfa Dyffryn is located directly behind the foredune in the north of foreland. The landform's deflation basin measured 
approximately $330 \mathrm{~m}$ long and $100 \mathrm{~m}$ at its widest point (Figure $2 \mathrm{c}$ ). The western trailing arm of the parabolic was an average of $18 \mathrm{~m}$ higher than the deflation basin, and the eastern trailing arm an average of $11 \mathrm{~m}$ higher than the deflation basin. The parabolic dune studied at Morfa Dyffryn has a deflation basin depth to width ratio of 0.15 .

\subsection{Braunton Burrows, England.}

Braunton Burrows is an $8 \mathrm{~km}^{2}$ coastal dune system located on the North Devon coast, extending 5.5 $\mathrm{km}$ north from the estuary of the Rivers Taw and Torridge. The parabolic studied at Braunton Burrows was in the south of the dune system, approximately $400 \mathrm{~m}$ inland and closely resembles the parabolic dune investigated by Willis et al. (1956) in Braunton Burrows. The deflation basin extends $410 \mathrm{~m}$ in length, $250 \mathrm{~m}$ in width and averages $12 \mathrm{~m}$ in depth (Figure $2 \mathrm{~d}$ and Table 1). The trailing arms are relatively well defined and have distinct ' $v$-shaped' morphology (Figure $2 \mathrm{~d}$ ).

\subsection{Drigg Dunes, England.}

Drigg dunes is a $5 \mathrm{~km}^{2}$ coastal dune system most of which is located within the Lake District National Park, Cumbria. The dune system extends $5 \mathrm{~km}$ from the River Esk estuary in the south to the village of Seascale in the north. The parabolic dune investigated at Drigg Dunes is located within the Drigg Dunes Local Nature Reserve which occupies the southern end of the dune system. The dune has a deflation basin depth of $8 \mathrm{~m}$ and deflation basin width of $46 \mathrm{~m}$, resulting in a relatively high deflation basin depth to width ratio of 0.17 . The deflation basin extended $225 \mathrm{~m}$ in length and has a 'hairpin' U-shaped morphology (Figure 2e) (Pye and Tsoar, 2008).

\subsection{Forvie, Scotland.}

The coastal dunes at Forvie, also known as 'the sands of Forvie' (Landsberg, 1956; RobertsonRintoul, 1990; Ritchie, 1992; 2000), are a National Nature Reserve in Aberdeenshire, Scotland, that extend $5 \mathrm{~km}$ north of the River Ythan estuary. The parabolic dune investigated at Forvie is situated on a high plateau in the north of the site, approximately $1.3 \mathrm{~km}$ inland from the rocky coast to the east (Ritchie, 2000) and is understood to be part of the system of dunes that Ritchie (1992) labelled 'parabolic complex 7' and defined as 'sand wave 2' by Landsberg (1956). The dune has distinct Vshaped morphology (Figure 2f), with a broad entrance spanning $166 \mathrm{~m}$ in width and a deflation basin depth of $7 \mathrm{~m}$, resulting in a basin depth to width ratio of 0.04 .

\subsection{Merthyr Mawr Warren, Wales.}

Merthyr Mawr Warren National Nature Reserve is a $3.4 \mathrm{~km}^{2}$ coastal dune field located between Porthcawl and Ogmore-by-Sea, in Mid Glamorgan, Wales. The parabolic dune investigated at 
Merthyr Mawr Warren is located in the south of the dune system approximately $50 \mathrm{~m}$ north of the River Ogmore and $350 \mathrm{~m}$ inland from the foredune (Figure $2 \mathrm{~g}$ ). The dune has a U-shaped morphology with a relatively broad deflation basin spanning $151 \mathrm{~m}$ at its entrance and a deflation basin depth of $10 \mathrm{~m}$, producing a deflation basin depth to width ratio of 0.07 . Substantial dune rehabilitation works were performed immediately north of the investigated dune at Merthyr Mawr Warren (Figure $2 \mathrm{~g}$ ), however, the surface and topography of the dune studied was unaffected.

\subsection{Sandscale Haws, England.}

Sandscale Haws National Nature Reserve is a $1.8 \mathrm{~km}^{2}$ coastal dune system located in Cumbria, England. The dune system is located on the southern shore of the Duddon estuary, $0.5 \mathrm{~km}$ north of Walney Island. The parabolic dune investigated at Sandscale is located in north of the National Nature Reserve approximately $100 \mathrm{~m}$ from the foredune ridge (Figure $2 \mathrm{~h}$ ). The dune has a relatively elongated U-shaped morphology, closely resembling a simple 'hairpin' (Tsoar and Pye, 2008). The deflation basin of the dune has a width of $135 \mathrm{~m}$ and was $8 \mathrm{~m}$ deep, generating a deflation basin depth to width ration of 0.06 .

\subsection{Summary of parabolic dune morphologies}

The eight dunes investigated represent a broad range of parabolic morphologies (Table 1). Deflation basin width, defined as the landforms upwind 'entrance', ranged from $46 \mathrm{~m}$ (Drigg Dunes) to $250 \mathrm{~m}$ (Braunton Burrows) (Table 1) and deflation basin depth, defined as the average height of the trailing arms, minus the average height of deflation basin, ranged from $6 \mathrm{~m}$ (Forvie and Newborough Warren) to $15 \mathrm{~m}$ (Morfa Dyffryn) (Table 1). The depth to width ratio calculated for each landform ranged from 0.04 (Forvie and Newborough Warren) to 0.17 (Drigg Dunes). Deflation basin surfaces were predominately vegetated with the exceptions of Morfa Dyffryn, Newborough Warren and Ravenmoels. At these sites a substantial area of bare sand within the landforms deflation basin was identifiable from aerial imagery (Figure 2). 
Table 1. Morphological details of the parabolic dunes studied. Sites at which nine incident wind directions were examined are shaded grey.

\begin{tabular}{|c|c|c|c|c|c|c|c|}
\hline Location & $\begin{array}{l}\text { Latitude and } \\
\text { longitude }\end{array}$ & $\begin{array}{l}\text { Deflation } \\
\text { basin } \\
\text { depth } \\
(\mathrm{m})\end{array}$ & $\begin{array}{l}\text { Deflation } \\
\text { basin } \\
\text { width }(\mathrm{m})\end{array}$ & $\begin{array}{l}\text { Deflation } \\
\text { basin } \\
\text { depth to } \\
\text { width ratio } \\
\end{array}$ & $\begin{array}{c}\text { Landform } \\
\text { orientation } \\
\left(^{\circ}\right)\end{array}$ & $\begin{array}{l}\text { Date of } \\
\text { LiDAR } \\
\text { survey }\end{array}$ & $\begin{array}{l}\text { Date of } \\
\text { aerial } \\
\text { image }\end{array}$ \\
\hline $\begin{array}{l}\text { Braunton } \\
\text { Burrows } \\
\text { (England) }\end{array}$ & $\begin{array}{c}51^{\circ} 04^{\prime} 36.1^{\prime \prime} \mathrm{N} \\
4^{\circ} 12^{\prime} 20.2^{\prime \prime W}\end{array}$ & 12 & 250 & 0.05 & 80 & 2015 & 2014 \\
\hline $\begin{array}{l}\text { Drigg Dunes } \\
\text { (England) }\end{array}$ & $\begin{array}{l}54^{\circ} 20^{\prime} 51.72 " \mathrm{~N} \\
3^{\circ} 25^{\prime} 41.97^{\prime \prime} \mathrm{W}\end{array}$ & 8 & 46 & 0.17 & 90 & 2013 & 2008 \\
\hline $\begin{array}{c}\text { Forvie } \\
\text { (Scotland) }\end{array}$ & $\begin{array}{l}57^{\circ} 20^{\prime} 44.96 " \mathrm{~N} \\
1^{\circ} 57^{\prime} 44.88^{\prime \prime} \mathrm{W}\end{array}$ & 7 & 166 & 0.04 & 7 & 2011 & 2011 \\
\hline $\begin{array}{c}\text { Merthyr Mawr } \\
\text { Warren (Wales) }\end{array}$ & $\begin{array}{c}51^{\circ} 28^{\prime} 26.66 " \mathrm{~N} \\
3^{\circ} 38^{\prime} 8.31^{\prime \prime W}\end{array}$ & 10 & 151 & 0.07 & 75 & 2015 & 2013 \\
\hline $\begin{array}{l}\text { Morfa Dyffryn } \\
\text { (Wales) }\end{array}$ & $\begin{array}{c}52^{\circ} 48^{\prime} 27.26 " \mathrm{~N} \\
4^{\circ} 8^{\prime} 40.57^{\prime \prime} \mathrm{W}\end{array}$ & 15 & 100 & 0.15 & 37 & 2015 & 2014 \\
\hline $\begin{array}{c}\text { Newborough } \\
\text { Warren (Wales) }\end{array}$ & $\begin{array}{l}53^{\circ} 8 ' 40.27 " \mathrm{~N} \\
4^{\circ} 21^{\prime} 45.26^{\prime \prime} \mathrm{W}\end{array}$ & 7 & 164 & 0.04 & 24 & 2015 & 2015 \\
\hline $\begin{array}{l}\text { Ravenmoels } \\
\text { Sandhills } \\
\text { (England) }\end{array}$ & $\begin{array}{c}53^{\circ} 32^{\prime} 27.39 " \mathrm{~N} \\
3^{\circ} 5^{\prime} 20.12 " \mathrm{~W}\end{array}$ & 11 & 117 & 0.09 & 64 & 2014 & 2015 \\
\hline $\begin{array}{c}\text { Sandscale } \\
\text { Haws (England) }\end{array}$ & $\begin{array}{l}54^{\circ} 10^{\prime} 7.38 " \mathrm{~N} \\
3^{\circ} 15^{\prime} 3.49 " \mathrm{~W}\end{array}$ & 8 & 135 & 0.06 & 90 & 2013 & 2014 \\
\hline
\end{tabular}

\section{Methodology}

Computational fluid dynamics modelling (Jackson et al., 2011; 2013; Smyth, 2016) was used to systematically model incident wind flow $\pm 60^{\circ}$ oblique to axis orientation of the deflation basin in $15^{\circ}$ increments at three sites: Newborough, Ravenmoels Sandhills and Morfa Dyffryn. These sites were selected as they represented a wide range of deflation basin widths, deflation basin depths and height to width deflation basin ratios (Table 1). To further support the conclusions from these three sites, incident winds $+45^{\circ}$ and -45 oblique to axis orientation of the deflation basin were simulated at an additional six sites. A maximum incident wind direction of + and $-45^{\circ}$ was selected as this was the largest oblique angle at which substantial flow steering was deemed to occur at the initial three sites without substantial flow separation and recirculation within deflation basin. An incident wind direction of $-60^{\circ}$, indicates that wind flow at the model inlet was $60^{\circ}$ anticlockwise from the axis orientation of the deflation basin, whereas an incident wind direction of $60^{\circ}$, indicates that wind flow at the model inlet was $60^{\circ}$ clockwise from the axis orientation of the deflation basin.

\subsection{Computational Fluid Dynamics Modelling}

Computational fluid dynamic (CFD) modelling was performed in OpenFOAM using the Semi-Implicit Method for Pressure Linked Equations (SIMPLE) algorithm. This method produces a time-averaged solution, using the Reynolds-averaged Navier-Stokes equations (RANS). Turbulence was modelled using the Re-normalisation group (RNG) $k-\varepsilon$ method as it compared well with measured wind flow 
over a large bowl blowout (Smyth et al., 2013) and barchan dune (Smith et al., 2017). Inlet conditions at each boundary were defined assuming a constant shear velocity $\left(u_{*}\right)$ value with height using equations 1, 2 and 3 (Richards and Hoxey, 1993; Blocken et al., 2007):

$$
\begin{aligned}
& U(z)=\frac{u *}{\kappa} \ln \left(\frac{z+z_{0}}{z_{0}}\right) \\
& k(z)=\frac{u_{*}^{2}}{\sqrt{C_{\mu}}} \\
& \varepsilon(z)=\frac{u_{*}^{3}}{\kappa\left(z+z_{0}\right)}
\end{aligned}
$$

Where $z$ is the height above the surface, $\kappa$ is the von Karman constant $(0.42), z_{0}$ is the surface roughness length and $C_{\mu}$ a constant of 0.09 (Richards and Hoxey, 1993). For all simulations, $z_{0}$ was prescribed a uniform value of $0.175 \mathrm{~m}$, the average median $z_{0}$ value measured in vegetated dune slacks by Levin et al. (2008). For all cases incident wind speed was prescribed at $11 \mathrm{~m} \mathrm{~s}^{-1}, 10 \mathrm{~m}$ above the surface $\left(u_{*}=1.14 \mathrm{~m} \mathrm{~s}^{-1}\right)$. This value corresponded to the average incident wind speed throughout the field experiment (measured at $6 \mathrm{~m}$ elevation at the south west entrance of the landform (Figure 3)) during which near continuous sediment transport was measured.

In all cases, the topographic surface of the study site was generated from a $2 \times 2 \mathrm{~m}^{2}$ resolution airborne LiDAR surveys performed between 2011 - 2015 (Table 1). Cell size in each computational domain decreased gradually size from $40 \times 40 \times 40 \mathrm{~m}$ at the top of the domain to $2.5 \times 2.5 \times 2.5 \mathrm{~m}^{3}$ at the surface throughout the domain. In all cases the inlet of the computational domain was at least $100 \mathrm{~m}$ upwind of the landform and the height of the computational domain at least five times greater than the highest topographic point. Wind data was probed $0.4 \mathrm{~m}$ above the surface of the dune, the same height as wind flow measured in the field. Calculations were considered complete once wind speed within the deflation basin reached a steady state (i.e. measurements of wind speed varied less than $0.01 \%$ between numerical iterations).

\subsection{Model Accuracy Assessment}

To evaluate the accuracy of the modelled wind speed and direction, modelled and measured wind speed and direction were compared at 21 points throughout the deflation basin at Ravenmoels (Figure 2a). A grid of instruments consisting of 21, 3D ultrasonic anemometers were located in the north east half of the landform, which was free of vegetation (Figure 3) (Full description in DelgadoFernandez et al., 2018). The instrumentation array covered a total area of $150 \mathrm{~m}$ by $100 \mathrm{~m}$, the maximum reach permitted by power and communication cables. A two-dimensional sonic anemometer was deployed at $6 \mathrm{~m}$ elevation at the south west entrance, to provide information on 
incident wind speed and direction (Figure 3). Instruments were deployed along a central (C) line connecting the beginning of the unvegetated basin (C1) with the depositional lobe (C6), and four transects perpendicular to the central line going from the basin up the northern erosional wall (N1 to N4 and N5 to N7) and southern erosional wall (S1 to S4 and S5 to S8) (Figures 3 and 10).

Ultrasonic anemometers within the parabolic dune were positioned at an elevation of $0.4 \mathrm{~m}$ above the surface with their horizontal stream plane orientated horizontally. Ultrasonic anemometers on top of the wall crests (N4, N7, S4, S8) were positioned $2 \mathrm{~m}$ above the surface to avoid interference with the dense vegetation below.

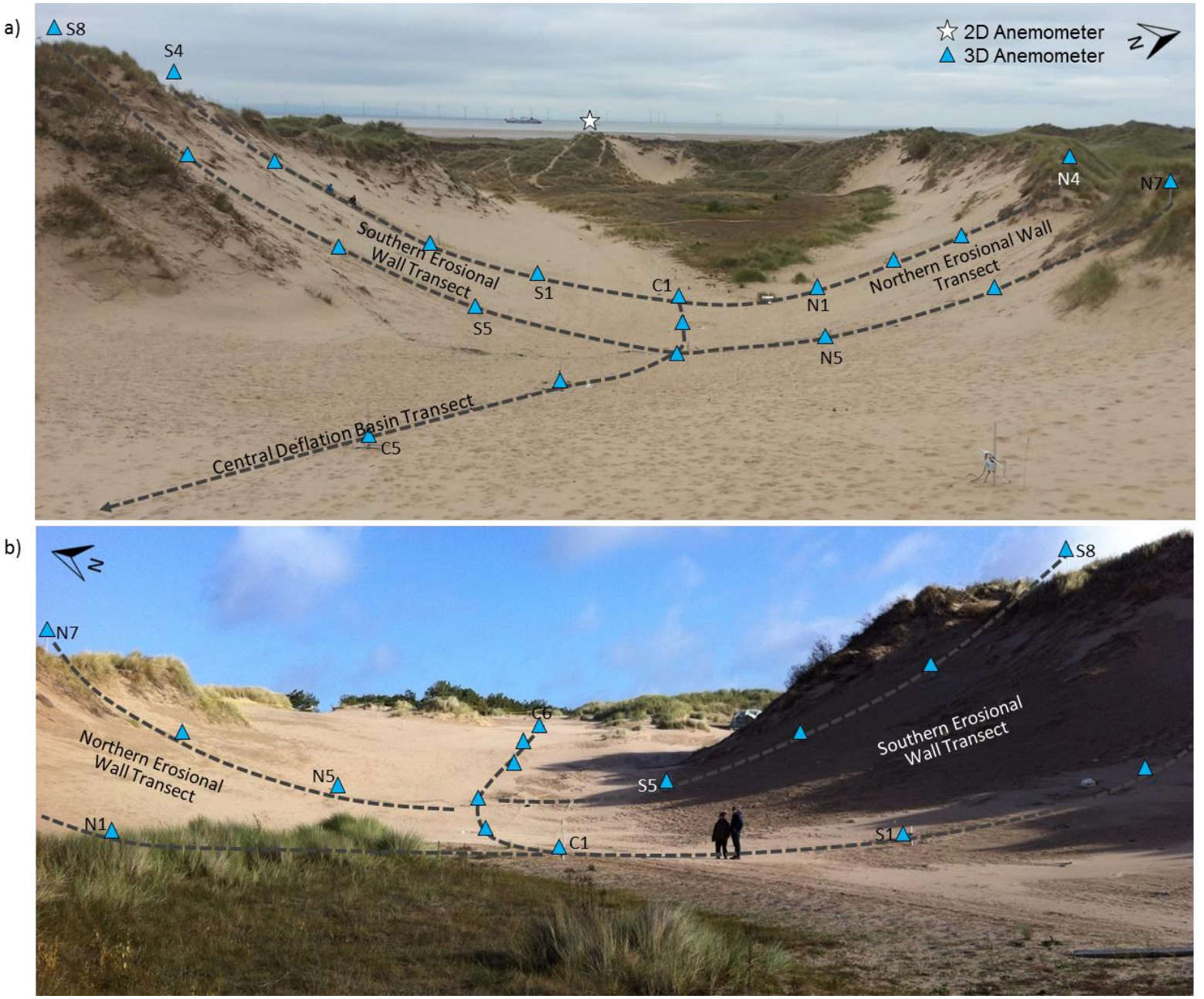

Figure 3. Seaward (a) and landward (b) views of the parabolic studied at Ravenmoels Sandhills and instrument grid. (Image adapted from Delgado-Fernandez et al. (2018)).

\section{Results}

\subsection{Modelled near surface wind flow}

To analyse the potential of wind flow steering, near surface $(0.4 \mathrm{~m})$ wind flow direction was plotted relative to the axis orientation of the landform's deflation basin (Figures $4-8$ ). The percentage of 
wind flow within the deflation basin steered $\pm 15^{\circ}$ relative landform was also calculated (Figures 4 7). A value of $\pm 15^{\circ}$ was selected as Finnigan et al., (1990) concluded that for an incident wind direction of $\pm 15^{\circ}$ relative to a parabolic dunes axis orientation, an established parabolic dune would be likely to retain its initial orientation. Therefore, the greater the proportion of the deflation basin the within $\pm 15^{\circ}$ of the landform's axis orientation, the greater likelihood the landform will continue to evolve in its antecedent orientation.

\subsubsection{Ravenmoels Sandhills}
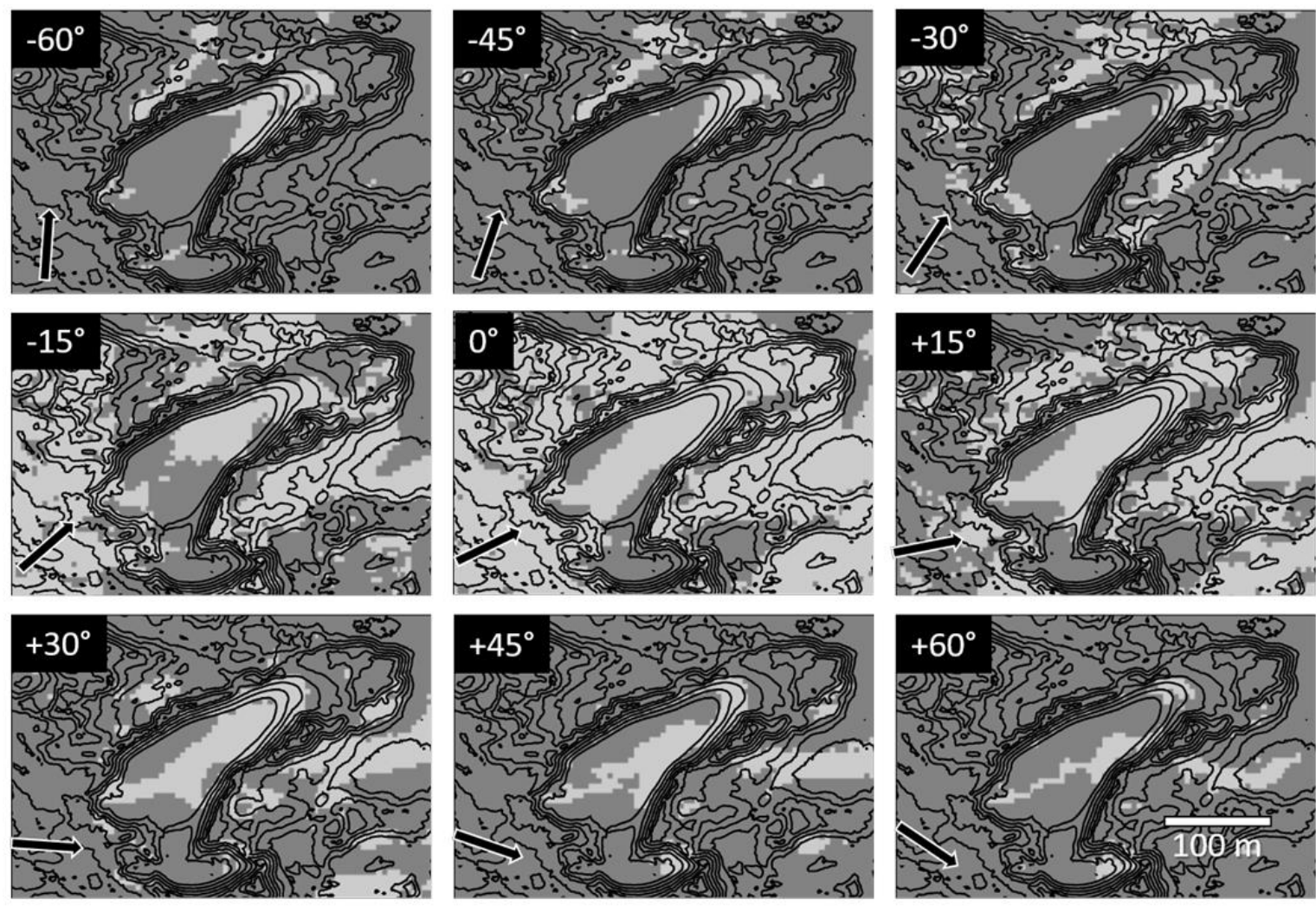

Wind direction $> \pm 15^{\circ}$ of the deflation basin orientation

Wind direction $\leq \pm 15^{\circ}$ of the deflation basin orientation

Figure 4 Wind direction $0.4 \mathrm{~m}$ above the surface at Ravenmoels Sandhills. Light grey represents wind flow direction $\pm 15^{\circ}$ of the deflation basin axis orientation $\left(244^{\circ}\right)$. Dark grey represents wind flow steered $> \pm 15^{\circ}$ of the deflation basin axis orientation. Arrow in bottom right of each panel represents incident wind direction. Contours represent a change in elevation of $\mathbf{2} \mathbf{m}$.

Figures 4 and 7 demonstrate that at Ravenmoels Sandhills, when the incident wind flow was aligned with the landform axis (incident wind direction of $0^{\circ}$ ), the majority $(77 \%)$ of wind flow within the deflation basin was orientated $\pm 15^{\circ}$ from the axis of the landform. As the incident wind flow became more oblique, the percentage of the deflation basin in which near surface wind flow is orientated $\pm 15^{\circ}$ from the axis of the landform declined in a Gaussian-like manner (Figure 7), however even for 
an incident wind flow of $+60^{\circ}, 15 \%$ of the deflation basin recorded wind flow orientated $\pm 15^{\circ}$ of the axis orientation of the deflation basin.

Figure 8a demonstrates that for all incident wind directions modelled at Ravenmoels Sandhills, wind direction along the central axis of the deflation basin (Figure 2a) became steered parallel to the axis orientation of the landform. This trend continues until approximately half-way up the stoss slope of the depositional lobe. At this point wind directions diverge again from the axis orientation of the landform and more closely reflect the incident wind direction. In contrast, in the south of the deflation basin, even when incident wind direction was directly parallel to the deflation basin $\left(0^{\circ}\right.$ in Figure $8 a$ ), $23 \%$ of the wind flow in the deflation basin had been steered greater than $15^{\circ}$ from the axis of the landform. This marked deviation from the incident wind direction was particularly evident in the southerly depositional walls of the landform for incident wind directions from the southsouth-west $\left(-60^{\circ}\right.$ to $\left.-15^{\circ}\right)$, where complex patterns of wind flow steering and recirculation occured as wind became separated and increased in turbulence as it entered the deflation basin over a steep erosional wall (Smyth et al., 2012; Delgado-Fernandez et al., 2018).

\subsubsection{Newborough Warren}

Of the three landforms at which nine incident wind directions were modelled, the parabolic dune at Newborough Warren demonstrated the least wind flow steering along the deflation basin relative to the landform's axis orientation. For incident winds $>15^{\circ}$ oblique to the axis orientation of the deflation basin, a maximum of $11 \%$ of the wind flow within the deflation basin is orientated $\pm 15^{\circ}$ relative to the deflation basin (Figures 5 and 7). When incident wind directions were $\pm 60^{\circ}$ oblique in relation to the axis orientation of the deflation basin, less than $1 \%$ of wind flow had been steered $\pm 15^{\circ}$ relative to the axis orientation. Figure $8 \mathrm{~b}$ does demonstrate that some minor steering of the wind flow toward to the orientation of the landform took place along the central transect of the deflation basin (Figure $2 \mathrm{~b}$ ), particularly for winds with an incidence angle $>45^{\circ}$ to the orientation of the landform. Figure $8 \mathrm{~b}$ also demonstrates wind flow became most steered relative to the orientation of the landform at the approximately one-third up the stoss slope of the depositional lobe. 

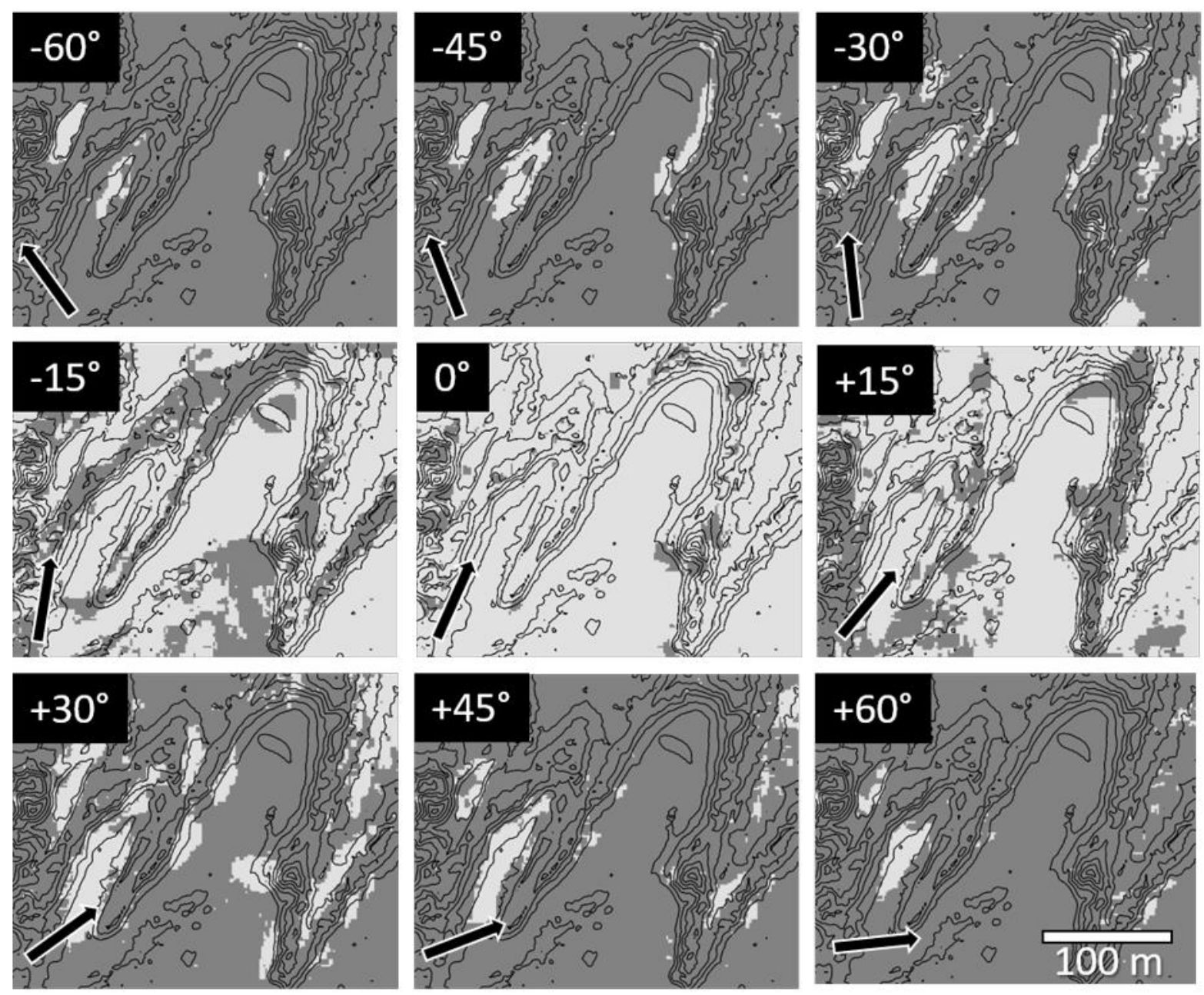

Wind direction $> \pm 15^{\circ}$ of the deflation basin orientation

Wind direction $\leq \pm 15^{\circ}$ of the deflation basin orientation

Figure 5. Wind direction $0.4 \mathrm{~m}$ above the surface at Newborough Warren. Light grey represents wind flow direction $\pm 15^{\circ}$ of the deflation basin axis orientation $\left(204^{\circ}\right)$. Dark grey represents wind flow steered $> \pm 15^{\circ}$ of the deflation basin axis orientation. Arrow in bottom right of each panel represents incident wind direction. Contours represent a change in elevation of $\mathbf{2} \mathbf{m}$.

\subsubsection{Morfa Dyffryn}

Wind flow within the deflation basin of the parabolic dune investigated at Morfa Dyffryn demonstrated greater amounts of flow realignment relative to landform axis orientation than Ravenmoels Sandhills and Newborough Warren (Figure 7). For winds from $-45^{\circ}$ and $+45^{\circ}$, an area totalling $44 \%$ of the deflation basin, was steered $\pm 15^{\circ}$ of the axis orientation of the landform $\left(217^{\circ}\right)$ (Figures 6 and 7). Figure $8 \mathrm{c}$ also illustrates the high degree of wind flow steering along the central axis of the deflation basin (Figure 2c). At Morfa Dyffryn wind flow within the deflation basin for all incident wind directions investigated became substantially steered parallel to the axis orientation of the landform, becoming most aligned with the axis orientation of the landform mid-way along the 
stoss slope of the depositional lobe. Wind direction along the central transect of the landform

(Figure 2c) for $-60^{\circ}$ incident wind flow demonstrates complex flow steering between $0 \mathrm{~m}$ and $100 \mathrm{~m}$ (Figure 8c). Analysis of the vectors of near-surface wind flow from the modelled wind flow data (not presented) indicates that the sudden change in wind direction was caused by complex secondary flow patterns as wind flow became separated as it entered the deflation basin over the steep slopes of the south-western trailing arm of the parabolic dune.
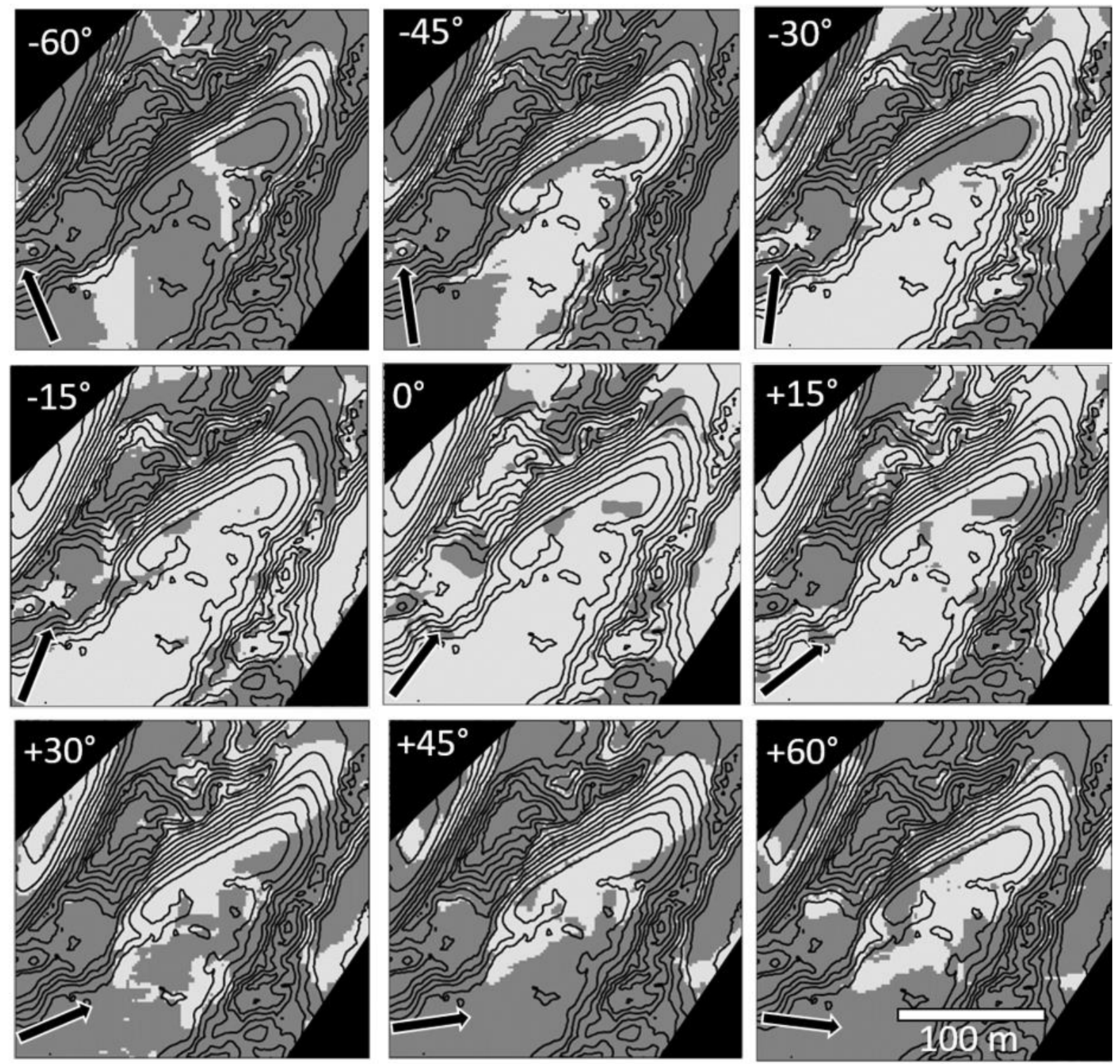

Wind direction $> \pm 15^{\circ}$ of the deflation basin orientation

Wind direction $\leq \pm 15^{\circ}$ of the deflation basin orientation

Figure 6. Wind direction $0.4 \mathrm{~m}$ above the surface at Morfa Dyffryn. Light grey represents wind flow direction $\pm 15^{\circ}$ of the deflation basin axis orientation $\left(217^{\circ}\right)$. Dark grey represents wind flow steered $> \pm 15^{\circ}$ of the deflation basin axis orientation. Arrow in bottom right of each panel represents incident wind direction. Contours represent a change in elevation of $2 \mathrm{~m}$. 


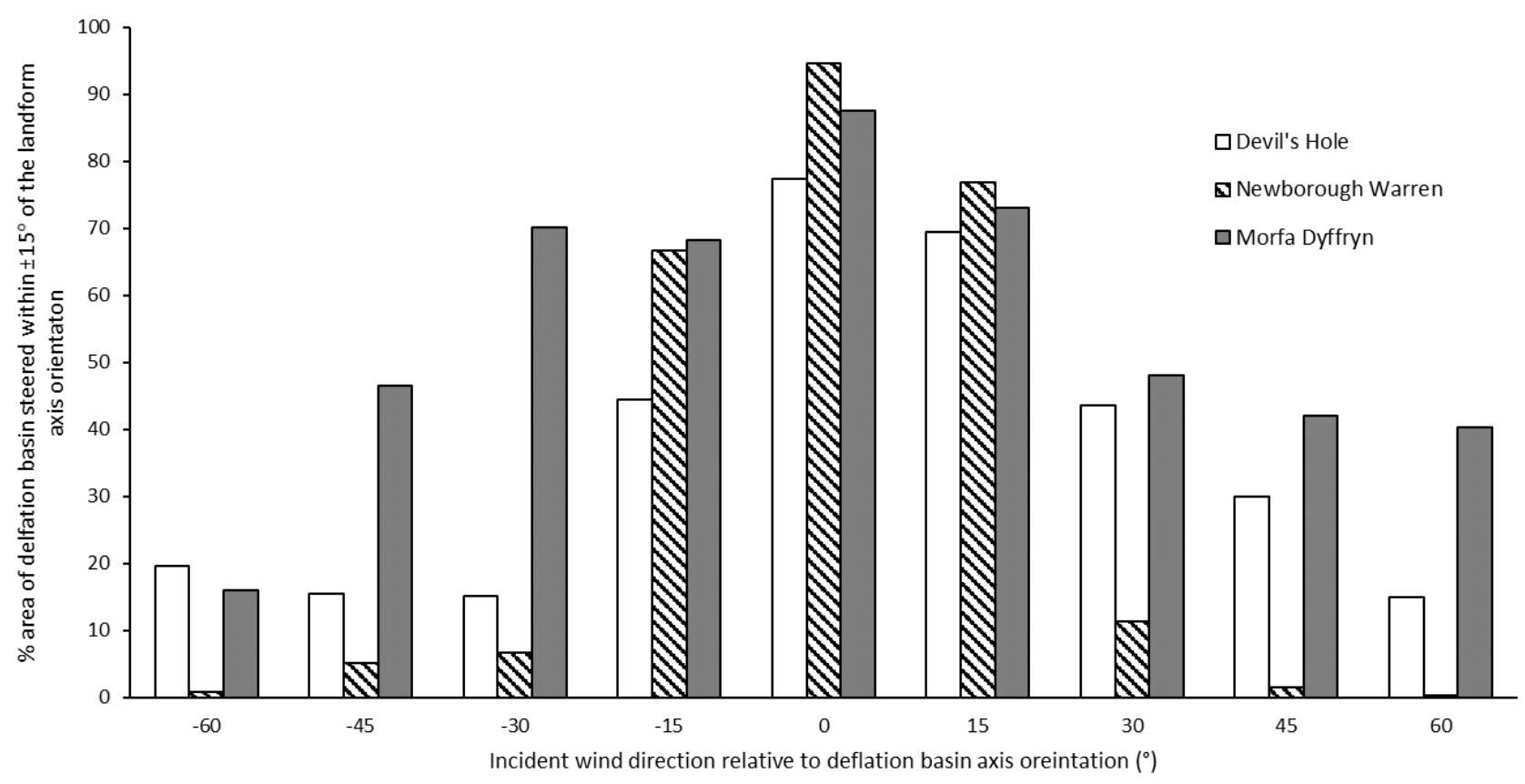

Figure 7. Percentage area of deflation basin steered $< \pm 15^{\circ}$ of the landforms axis orientation. The extent of each landforms deflation basin can be observed in Figure 2 . 

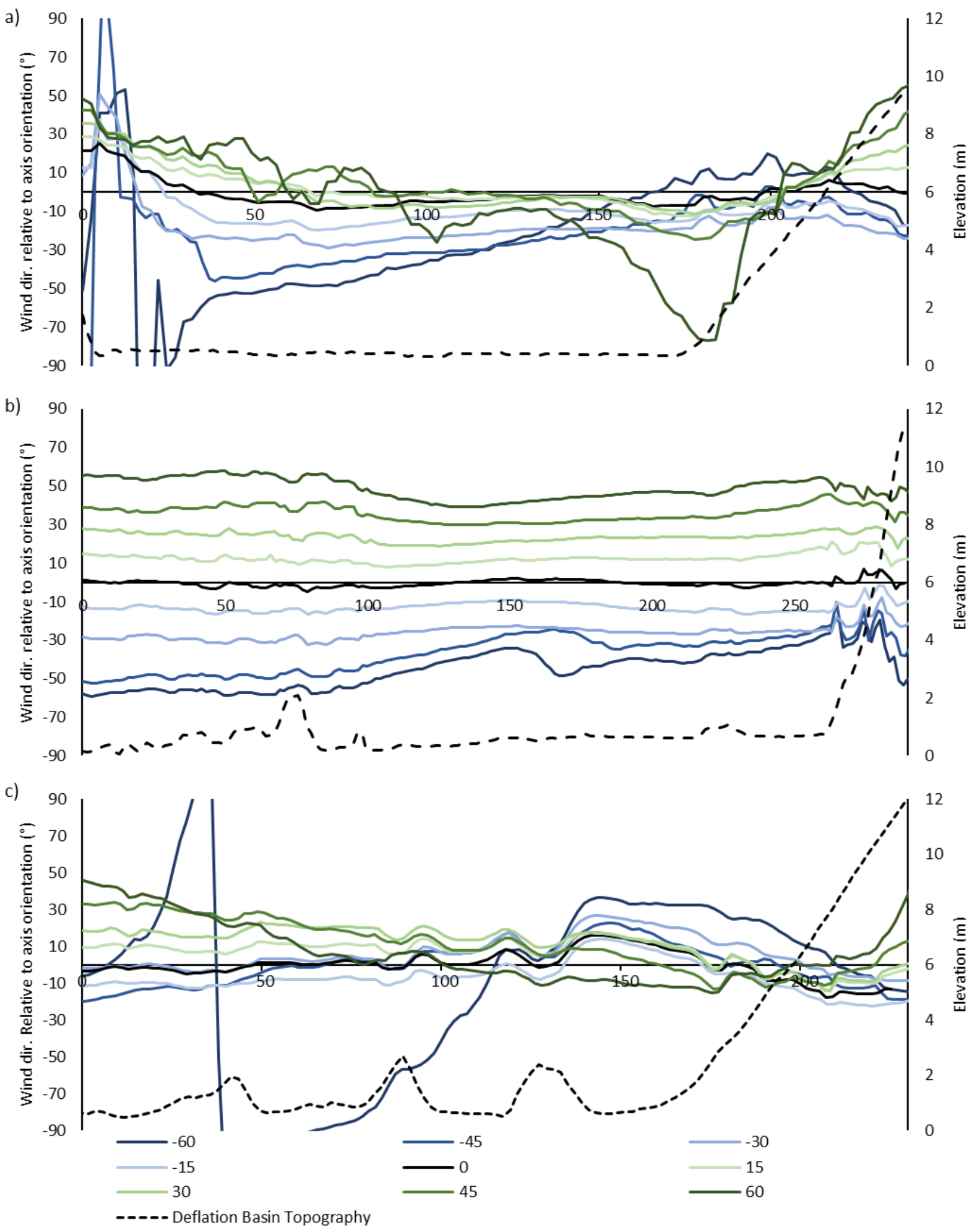

Figure 8. Wind direction and topography along the central transect of the deflation basin for the Ravenmoels Sandhills (a), Newborough Warren (b) and Morfa Dyffryn (c). The elevation datum has been normalised to $\mathbf{0}-\mathbf{3 0 . 6} \mathrm{m}$ to increase comparability between landforms. The location of the transect line for each landform can be observed in Figure 2. 

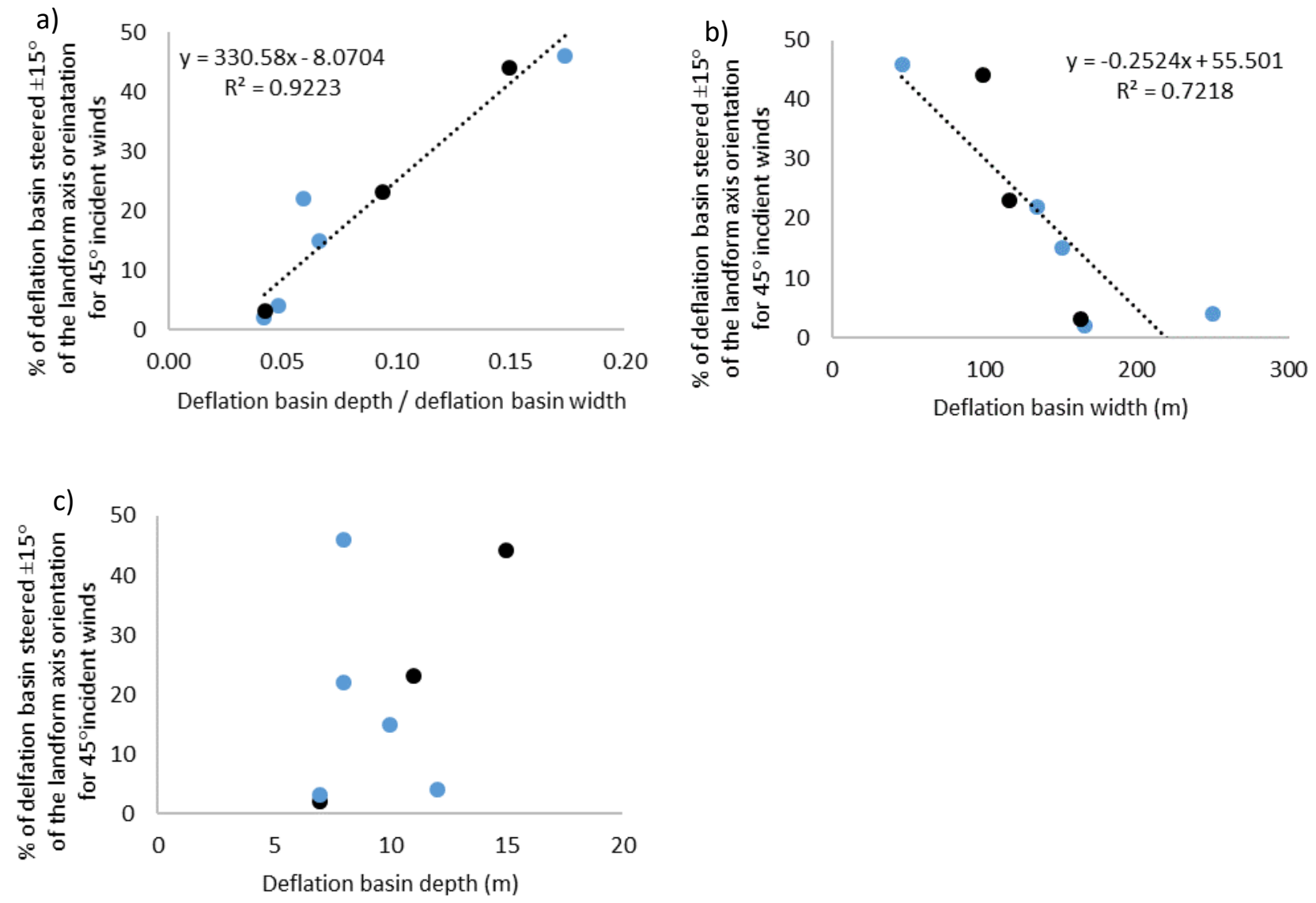

Figure 9. Scatter plots showing the relationships between percentage of deflation basin steered and depth-width ratio of the landform (a), deflation basin width (b), and deflation basin depth (c). Black dots represent sites at which incident wind flow was simulated from nine directions and blue dots represent sites at which incident wind direction was simulated from two wind directions.

To further test the hypothesis that the extent of near-surface wind flow reorientation relative to axis orientation is related to parabolic dune morphometry, incident wind flow + and $-45^{\circ}$ of the landform axis orientation at an additional five parabolic dunes (Section 2) was modelled. Deflation basin depth, deflation basin width and deflation basin depth to width ratio were used as independent variables to analyse the relationship between wind flow steering and morphometry for all eight parabolic dunes (Table 1). An incident wind direction $\pm 45^{\circ}$ relative to the axis orientation of each landform was used as modelling results from Ravenmoels Sandhills (Section 4.1.2) and Morfa Dyffryn (Section 4.1.3.) indicated that for an incident wind direction greater than $45^{\circ}$ relative to axis orientation of the landform, wind flow became separated with the deflation basin.

The results of all nine dunes modelled demonstrated a strong linear correlation $\left(R^{2}=0.91\right.$, Pearson $R$ $=0.96, p<0.01$ ) between the capacity for wind flow to be steered relative to the axis orientation of the parabolic dune and deflation basin height to width ratio (Figure 9a). The strength of the 
relationship suggests that the $\%$ of the deflation basin which is steered $\pm 15^{\circ}$ to the orientation of the landform can be statistically predicted by the equation $y=330.58 x-8.0704$, where $y$ is the $\%$ of steering within the deflation basin, and $\mathrm{x}$ the depth-width ratio of the deflation basin. A very strong negative correlation $\left(R^{2}=0.72\right.$, Pearson $\left.R=-0.85 p<0.01\right)$ was modelled between the width of the 'entrance' of the parabolic dune and the $\%$ of the deflation basin which is steered $\pm 15^{\circ}$ to the axis orientation of the landform (Figure 9b). No significant correlation was calculated between deflation basin depth and the extent of wind flow steering relative to the axis orientation of the deflation basin for $45^{\circ}$ incident winds (Figure 9c). The results demonstrate that the relationship between deflation basin width and depth is a critical factor in governing the extent of flow steering within the deflation basin of a parabolic dune.

\subsection{Field measurements and computational fluid dynamics comparison}

To test the performance of the computational fluid dynamics model, measured and modelled wind speed and direction within the parabolic dune at Ravenmoels Sandhills were compared (Figure 10). Wind flow data in the field was measured for a 20-minute period between 10:06 and 10:26 on $22^{\text {nd }}$ October 2015. Average wind speed immediately upwind of the deflation basin at the 2D anemometer recorded an average wind speed of $13.64 \mathrm{~m} \mathrm{~s}^{-1}$ and direction $+37^{\circ}$ relative to the axis orientation of the landform $\left(281^{\circ}\right)$. Incident wind direction during the measurement period was very constant, as demonstrated by a standard deviation of $1.54^{\circ}$.

Within the deflation basin wind flow along the northern erosional wall recorded the lowest wind speeds $\left(4-7 \mathrm{~m} \mathrm{~s}^{-1}\right)$. In contrast, anemometers located on the southern erosional wall measured the highest values $\left(6-15 \mathrm{~m} \mathrm{~s}^{-1}\right.$ ) (Figure 10). Wind speed along the deflation basin gradually increased with distance towards the depositional lobe, from a speed of $6.1 \mathrm{~m} \mathrm{~s}^{-1}$ at $\mathrm{C} 1$ to $7.0 \mathrm{~m} \mathrm{~s}^{-1}$ at $\mathrm{C} 6$. 

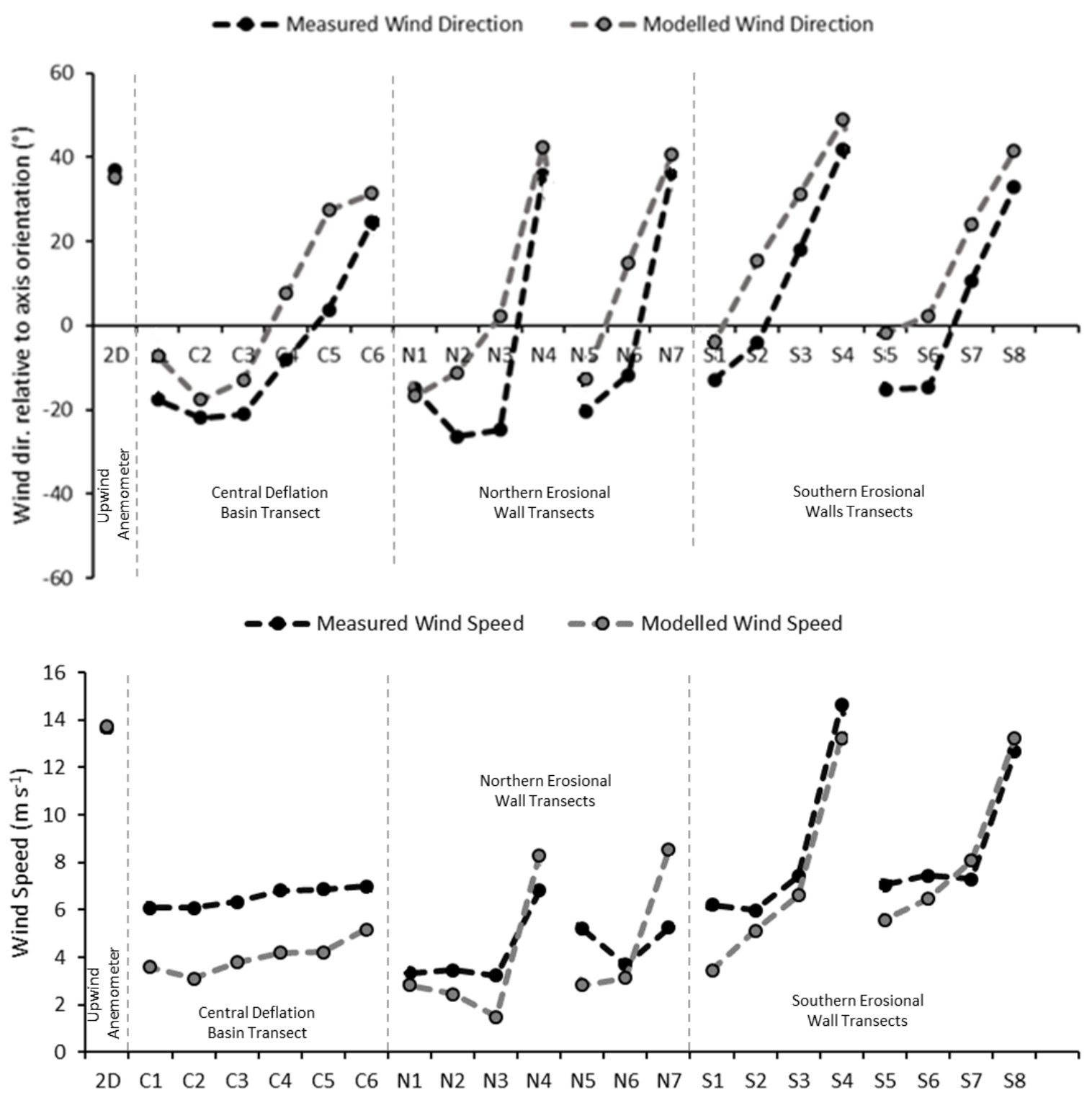

Figure 10. Comparison of wind speed and wind direction measured in the field (20 minute average) and modelled using computational fluid dynamics.

With regards to wind direction, at anemometers located in the deflation basin $(C 1, C 2, C 3, N 2, N 3$, $\mathrm{N} 5, \mathrm{~N} 6, \mathrm{~S} 1, \mathrm{~S} 2, \mathrm{~S} 5, \mathrm{S6})$, wind flow was steered $\pm 15^{\circ}$ of the central axis of the deflation basin $\left(244^{\circ}\right)$. Wind direction recorded at anemometers nearer to the crests of the erosional walls was closer in orientation to the incident wind direction $\left(281^{\circ}\right)$.

Wind direction calculated by the computational fluid dynamics model compared favourably with the measurements made in the field (Figure 10). In all locations, except N1, the extent of flow steering was under predicted by the computational fluid dynamics model, i.e. modelled wind flow direction was closer to the incident wind direction than measured. Overall a strong correlation between measured and modelled wind direction was demonstrated $\left(R^{2}=0.89, n=21, p<0.01\right)$. 
With regards to measured and modelled wind speed (Figure 10), modelled wind speed was substantially lower than measured wind speed along the central deflation basin $(\mathrm{C} 1-\mathrm{C} 6)$, however both datasets displayed a similar trend of increasing wind speed with distance along the axis of deflation basin. With regards to the two transects along the northern erosional wall of the landform (Figure 10), both measured and modelled wind speed demonstrated very similar trends for the N1 $\mathrm{N} 4$ transect. The agreement between the N5 - N7 transect was relatively weak, with the greatest discrepancy between measured and modelled wind speed at N7 located on the rim of the deflation basin. At this location modelled wind speed was substantially faster than measured. On the higher and morphologically simpler southern erosional wall measured and modelled wind speed were in very close agreement. Overall a robust correlation between measured and modelled wind speed was present $\left(R^{2}=0.81, n=21, p<0.01\right)$.

\section{Discussion}

The dependence of landform morphology to dictate near-surface flow dynamics may explain the discrepancy between the extent of wind flow steering reported by Finnigan et al. (1990) and Hansen et al. (2009). For incident winds $30^{\circ}$ oblique to the axis orientation of the landform, Finnigan et al. (1990) reported that the dune was no longer steering the wind. In contrast, Hansen et al. (2009) reported that when winds were from the south south west (approximately $60^{\circ}$ oblique to the axis orientation of the landform), wind flow within the parabolic dune was roughly parallel to the axis orientation of the landform. From the wind flow results presented by Hansen et al. (2009), we can postulate that the dune they investigated had a relatively high deflation basin depth to width ratio. Morphometric analysis of the 2012 dune surface (10 years after the measurements made by Hansen et al., 2009) supports this, as the dune has a depth to width deflation basin ratio of 0.18 , indicating a landform with a high capacity to steer incident wind flow relative to dune orientation (Figure 9a). Unfortunately, the depth of the deflation basin relative to the trailing arms for the landform studied by Finnigan et al. (1990) is not presented, nor can the site be accurately identified by remotely sensed data, preventing direct comparison with the results presented in this study. Although the authors hypothesise that the deflation basin of parabolic dunes with a high depth to width ratio may continue to migrate in the direction of an antecedent prevailing wind direction, wind flow patterns measured on the depositional lobe, outside of the deflation basin by Finnigan et al. (1990), Hansen et al., (2009) and in this study (Figure 8), indicate that wind directions return to the prevailing wind direction. This may result in an asymmetric morphology in the lee of the deflation basin regardless of the deflation basin depth to width ratio. 
The amount of wind flow steering along the central line of the deflation basin in figures $8 \mathrm{a}$ and $8 \mathrm{c}$, also demonstrates that wind flow steering parallel to the deflation basin becomes disrupted with incident wind flows with an obliquity greater than $45^{\circ}$. From very oblique angles wind flow becomes separated as it enters the deflation basin over the landforms steep trailing arms, forming complex patterns of flow reversal and steering. Similar wind flow behaviour has been documented within the parabolic dune modelled by Finnigan et al. (1990) and in bowl blowouts where incident wind flow enters over a steep erosional wall (Hesp and Walker, 2012; Smyth et al., 2012; Yurk et al., 2014; Smyth et al., 2019).

The results of this study indicate that using parabolic dune orientation as a proxy for prevailing wind direction must be done with caution and knowledge of landform morphology. Only in landforms with a relatively low deflation basin depth-width ratio $(<0.04)$, does little to no flow steering occur (e.g. Newborough Warren). In landforms with a greater ratio (>0.04), e.g. Ravenmoels Sandhills and Morfa Dyffryn, wind flow up to $60^{\circ}$ oblique to the orientation of the landform is steered parallel to the direction of the deflation basin. As a result of this form-flow feedback, if the prevailing wind for a region changes, the deflation basin may continue to migrate in the direction in which the deflation basin was established. This process may enable dune migration direction to decouple from contemporary prevailing wind conditions. The authors advise that future studies should apply caution when analysing parabolic dunes as a proxy for prevailing wind direction, and preferably only use landforms with a relatively low deflation basin depth to height ratio. This wariness is further reinforced by the comparison of measured and modelled wind direction data (Figure 10) which shows that the modelled results presented in this study may be under predicting the extent of wind flow steering within the landform. Morphometric analysis of landforms to assess the width-height ratio, is increasingly feasible and efficient using remotely sensed data from methods such as LiDAR and unmanned aerial vehicle topographic surveys. For parabolic dunes with a large depth to width ratio, at best, all that can be extrapolated from landform orientation is the wind direction when the landform was established.

\section{Conclusion}

Our results demonstrate, for the first time, that the effectiveness of a parabolic dune to steer oblique incident wind flow is strongly governed by the depth to width ratio of the deflation basin. The higher the ratio, i.e. the deeper and narrower it is, the greater the amount of flow steering within the deflation basin.

This study questions the full validity of using parabolic dunes as a proxy for prevailing wind direction. Modelled near surface wind flow dynamics indicate that parabolic dunes with a relatively high 
depth/width ratio (e.g. > 0.04) may continue to migrate relative to the wind direction under which they were established, rather than contemporary conditions. Future studies should apply caution when analysing parabolic dunes as proxies for prevailing wind direction, and preferably only use landforms with a relatively low deflation basin depth to width ratio.

\section{References}

Anthonsen KL, Clemmensen LB and Jensen, JH (1996) Evolution of a dune from crescentic to parabolic form in response to short-term climatic changes: Råbjerg Mile, Skagen Odde, Denmark. Geomorphology, 17(1-3): 63-77.

Ardon K, Tsoar H and Blumberg DG (2009) Dynamics of nebkhas superimposed on a parabolic dune and their effect on the dune dynamics. Journal of Arid Environments, 73(11): 1014-1022.

Arens SM, Slings Q and De Vries CN (2004) Mobility of a remobilised parabolic dune in Kennemerland, The Netherlands. Geomorphology, 59(1): 175-188.

Bailey SD and Bristow CS (2004) Migration of parabolic dunes at Aberffraw, Anglesey, north Wales. Geomorphology, 59(1): 165-174.

Bauer BO, Walker IJ, Baas AC, Jackson DW, McKenna-Neuman C, Wiggs GF and Hesp PA (2013) Critical reflections on the coherent flow structures paradigm in aeolian geomorphology. Coherent Flow Structures at Earth's Surface, pp.111-134.

Blocken B, Stathopoulos T and Carmeliet J (2007) CFD simulation of the atmospheric boundary layer: wall function problems. Atmospheric environment, 41(2): 238-252.

Burrough PA and McDonell RA (1998) Principles of Geographical Information Systems (Oxford University Press, New York), 190 pp.

Delgado-Fernandez I, Smyth, TAG, Jackson, DWT, Smith AB and Davidson-Arnott RG (2018) Eventscale dynamics of a parabolic dune and its relevance for mesoscale evolution. Journal of Geophysical Research: Earth Surface, 123(11): 3084-3100.

Durán O, Silva MVN, Bezerra LJC, Herrmann HJand Maia LP (2008) Measurements and numerical simulations of the degree of activity and vegetation cover on parabolic dunes in north-eastern Brazil. Geomorphology, 102(3): 460-471.

Esteves LS, Brown JM, Williams JJ and Lymbery G (2012), Quantifying thresholds for significant dune erosion along the Sefton Coast, Northwest England, Geomorphology, 143, 52-61, doi.org/10.1016/j.geomorph.2011.02.029.

Finnigan JJ, Neil D, Lees BG, Croome RJ and Woodgate M (1990) Modelling the wind flow pattern around a parabolic sand dune. Mathematics and computers in simulation, 32(1-2): 89-94.

Girardi JD and Davis DM (2010) Parabolic dune reactivation and migration at Napeague, NY, USA: Insights from aerial and GPR imagery. Geomorphology, 114(4): 530-541.

Gillies JA, Nield JM and Nickling WG (2014) Wind speed and sediment transport recovery in the lee of a vegetated and denuded nebkha within a nebkha dune field. Aeolian Research, 12, pp.135-141. 
Goudie A (2011) Parabolic dunes: distribution, form, morphology and change. Ann. Arid Zone, 50: 17.

Hansen E, DeVries-Zimmerman S, van Dijk D and Yurk B (2009) Patterns of wind flow and aeolian deposition on a parabolic dune on the southeastern shore of Lake

Michigan. Geomorphology, 105(1): 147-157.

Hesp PA and Smyth TA (2016) Jet flow over foredunes. Earth Surface Processes and Landforms, 41(12): 1727-1735.

Hesp PA and Walker IJ (2012) Three-dimensional aeolian dynamics within a bowl blowout during offshore winds: Greenwich dunes, Prince Edward Island, Canada. Aeolian Research, 3(4): 389-399.

Hugenholtz CH and Wolfe SA (2005) Recent stabilization of active sand dunes on the Canadian prairies and relation to recent climate variations. Geomorphology, 68(1): 131-147.

Jennings JN (1957) On the orientation of parabolic or U-dunes. The Geographical Journal, 123(4): $474-480$

Jackson DWT, Beyers JHM, Delgado-Fernandez I, Baas ACW, Cooper JAG and Lynch K (2013) Airflow reversal and alternating corkscrew vortices in foredune wake zones during perpendicular and oblique offshore winds. Geomorphology, 187:86-93.

Jackson DWT, Beyers JHM, Lynch K, Cooper JAG, Baas ACW and Delgado-Fernandez I (2011) Investigation of three-dimensional wind flow behaviour over coastal dune morphology under offshore winds using computational fluid dynamics (CFD) and ultrasonic anemometry. Earth Surface Processes and Landforms, 36(8):1113-1124.

Jackson DWT, Bourke MC and Smyth TAG (2015) The dune effect on sand-transporting winds on Mars. Nature communications, 6, p.8796.

Kilibarda Z, Venturelli R and Goble R (2014) Late Holocene dune development and shift in dunebuilding winds along southern Lake Michigan. Coastline and Dune Evolution along the Great Lakes. Geological Society of America Special Paper, 508: 47-64.

Kiss T, Sipos $G$ and Kovács $F$ (2009) Human impact on fixed sand dunes revealed by morphometric analysis. Earth Surface Processes and Landforms, 34(5): 700-711.

Landsberg SY (1956) The orientation of dunes in Britain and Denmark in relation to wind. The Geographical Journal, 122(2): 176-189.

Levin N, Ben-Dor E, Kidron GJ and Yaakov Y (2008) Estimation of surface roughness (z0) over a stabilizing coastal dune field based on vegetation and topography. Earth Surface Processes and Landforms, 33(10): 1520-1541.

Lynch K, Jackson DWT and Cooper JAG (2010) Coastal foredune topography as a control on secondary airflow regimes under offshore winds. Earth Surface Processes and Landforms: The Journal of the British Geomorphological Research Group, 35(3), pp.344-353.

Maltby RL (1962) Flow visualization in wind tunnels using indicators. Advisory group for aeronautical research and development, Paris (France) 
McInnes KL, Erwin TA and Bathols JM (2011) Global Climate Model projected changes in $10 \mathrm{~m}$ wind speed and direction due to anthropogenic climate change. Atmospheric Science Letters, 12(4): 325333.

Pye K (1982) Morphological development of coastal dunes in a humid tropical environment, Cape Bedford and Cape Flattery, North Queensland. Geografiska Annaler. Series A. Physical Geography: 213-227.

Pye K and Tsoar H (2008) Aeolian sand and sand dunes. Springer Science \& Business Media.

Read S (1995) The development of Devil's Hole 1945 - 1995 Ravenmeols, Formby, Lancashire. A detailed topographic and ecological study. B.Sc. Dissertation held at Ainsdale Discovery Centre, Merseyside, NW England.

Richards PJ and Hoxey RP (1993) Appropriate boundary conditions for computational wind engineering models using the $k-\epsilon$ turbulence model. Journal of wind engineering and industrial aerodynamics 46: 145-153.

Ritchie W (1992) Scottish landform examples -4 Coastal parabolic dunes of the Sands of Forvie. Scottish Geographical Magazine, 108(1): 39-44.

Ritchie W (2000) The sands of Forvie (Scotland): A case study in geomorphology and conservational management. Journal of Coastal Conservation, 6(2), pp.207-218.

Robertson-Rintoul MJ (1990) A quantitative analysis of the near-surface wind flow pattern over coastal parabolic dunes. Coastal dunes: 57-78.

Savory $\mathrm{E}$ and Toy $\mathrm{N}$ (1986) The flow regime in the turbulent near wake of a hemisphere. Experiments in Fluids, 4(4), pp.181-188.

Smith AB, Jackson DW and Cooper, JAG (2017) Three-dimensional airflow and sediment transport patterns over barchan dunes. Geomorphology, 278, pp.28-42.

Smyth TA (2016) A review of Computational Fluid Dynamics (CFD) airflow modelling over aeolian landforms. Aeolian research, 22: 153-164.

Smyth TAG, Hesp PA, Walker IJ, Wasklewicz T, Gares PA and Smith AB (2019) Topographic change and numerically modelled near surface wind flow in a bowl blowout. Earth Surface Processes and Landforms.

Smyth TAG, Jackson DWT and Cooper JAG (2012) High resolution measured and modelled threedimensional airflow over a coastal bowl blowout. Geomorphology, 177: 62-73.

Smyth TAG, Jackson DWT and Cooper JAG (2013) Three dimensional airflow patterns within a coastal trough-bowl blowout during fresh breeze to hurricane force winds. Aeolian Research, 9: 111-123.

Sutton SLF and Neuman CM (2008) Sediment entrainment to the lee of roughness elements: Effects of vortical structures. Journal of Geophysical Research: Earth Surface, 113(F2).

Wolfe SA and David PP (1997) Parabolic dunes: examples from the Great Sand Hills, southwestern Saskatchewan. The Canadian Geographer/Le Géographe canadien, 41(2): 207-213.

Wolfe SA and Hugenholtz $\mathrm{CH}$ (2009) Barchan dunes stabilized under recent climate warming on the northern Great Plains. Geology, 37(11): 1039-1042. 
Yan N and Baas AC (2015) Parabolic dunes and their transformations under environmental and climatic changes: towards a conceptual framework for understanding and prediction. Global and Planetary Change, 124: 123-148.

Yurk B, Hansen EC, DeVries-Zimmerman S, Kilibarda Z, van Dijk D, Bodenbender B, Krehel A and Pennings $T$ (2014) The role of extratropical cyclones in shaping dunes along southern and southeastern Lake Michigan. Geological Society of America Special Papers, 508: 167-194. 